\title{
Determination of Watershed Boundaries in Turkey by GIS Based Hydrological River Basin Coding
}

\author{
Y. Darama1, K. Seyrek ${ }^{2}$ \\ ${ }^{1}$ Civil Engineering Department, Atılım University, Ankara, Turkey \\ ${ }^{2}$ Technology Department, State Hydraulic Works (DSI), Ankara, Turkey \\ Email: yakup.darama@atilim.edu.tr
}

How to cite this paper: Darama, Y. and Seyrek, K. (2016) Determination of Watershed Boundaries in Turkey by GIS Based Hydrological River Basin Coding. Journal of Water Resource and Protection, 8, 965-981. http://dx.doi.org/10.4236/jwarp.2016.811078

Received: June 7, 2016

Accepted: October 10, 2016

Published: October 13, 2016

Copyright $\odot 2016$ by authors and Scientific Research Publishing Inc. This work is licensed under the Creative Commons Attribution International License (CC BY 4.0).

http://creativecommons.org/licenses/by/4.0/ (c) (i) Open Access

\begin{abstract}
A study was performed to develop hydrological river basin coding for Turkish river basins using the pfafstetter coding system. The coding system developed in this study is based on the combination of ECRINS and pfafstetter methods. River Basin District concepts were incorporated in this method so that it can be applicable to the management of Turkish River Basins. Developed hydrological river basin coding system is flexible, versatile and fits to all types of basins in Turkey. In order to show the efficiency of the coding system, it was applied to three river basins each of which has different hydrological and topographical features from the others. The basins used for the application of the coding system have complex features such as being transboundary basins, or being coastal basins whose discharge is not joining to the main drainage system, or being a closed basin discharging to an inland lake. Using the developed hydrological river basin coding defines river basin boundaries accurately, preventing conflicts in sectorial water allocation that are caused by uncertainty in the locations of water sources, producing a base for determining water potential and estimating extreme hydrological events of the basin, producing a basis for the prevention of water disputes among stakeholders within the basin, and helping implementation of Integrated Water Resources Management (IWRM) at basin level.
\end{abstract}

\section{Keywords}

Water Resources Management, Hydrological Basin Coding, GIS

\section{Introduction}

Even though demand on water utilization has been increasing as a result of the increase in world population, industrialization and urbanization, the water resources potential 
stays constant. Furthermore, increase in agricultural activities, expansion of industrial and metropolitan urban areas and the effects of the climate change have severe adverse effects, decreasing land resources and putting pressure on water resources. Therefore, effective management of land and water resources becomes important. One of the key elements to achieve an effective water management is setting up technological infrastructures that provide gathering and storing of all relevant data on water resources. It is not easy to find appropriate data every time for a particular basin at the same quality and resolution. As such, remote sensing and GIS technologies gain importance for gathering data in the implementation of Integrated Water Resources Management (IWRM) plans. Implementation of IWRM effectively requires knowledge in basin dynamics, surface and groundwater resources potential of the basin and daily sectorial water consumption in the basin. Stakeholders in the basin should have an access to all those information related to the basin. In this context, many countries have collected basinwide water data and established National Water Information Systems to store this data and share it with the public. European Environmental Agency together with the member countries is conducting a web based study on Water Information System for Europe within the context of the Water Framework Directive.

Implementation of IWRM effectively also requires a systematic definition of the watershed together with all lower level components. Basin, sub-basin definition should be considered within this context, and basin topologies should be established hierarchically. It is very important to define a unique code for each branch of the river network draining the basin. Even though studies related to basin and sub basin drainage system coding have been performed in many European countries, European Union still conducts studies known as "European Rivers and Catchments-ERICA" and "European Catchments and Rivers Network Systems-ECRINS" to provide a common coding base for determining accurately the basin and sub basin river network systems. In Turkey, determination of basin-sub basin drainage systems has been done by using a classical approach. With hydrologic perspective, Turkey was divided into 25 main basins, and some of the sub basins were determined during the water resources development projects in these basins. The recent development of computer technologies and Geographic Information Systems (GIS) and use of these tools in water sources management projects in those basins in Turkey helped engineers and water scientists. Various organizations in Turkey who are working in water sector, are using GIS technologies actively, especially in determining the study area's hydrologic drainage characteristic for water resources project development. However, none of these studies systematically approached the determination of basin and sub basing drainage system coding.

Impacts of climate change affected the hydrology of watersheds adversely, and watershed authorities have been facing serious challenges in terms of reduction of water potential. Thus, water allocation among agriculture, hydropower, industry and domestic usage sectors became very important. Significant changes in magnitude and intensity of precipitation in basins caused problems in flood risk management. These challenges cause problems in water transmission between basins not only in one country but also for transboundary watersheds located in arid and semiarid regions. Thus engi- 
neers and water resources scientists have been working on these problems by using satellite information and GIS technologies to obtain solutions for these problems. Thus effective and accurate solution of water resources problems at basin scale requires the determination of watershed boundary, shape and size by determining river drainage network accurately and studying the drainage characteristics of the basin by using digital elevation models. Numerous studies may be found in literature for stream ordering [1] [2]. Horton provided the theoretical basis for quantitative analysis of drainage network structures [3]. He defined the main branch of a river discharging to a sea, lake or ocean as the first degree stream and all the branches joining to this main branch as the second degree streams, and the branches joining to the second degree streams as the third order streams and so on. In this definition the highest degree streams in the basin receive only the overland flow. The method that was defined by Horton for stream ordering has two stages [4]. In the first stage he defined the streams receiving only overland flow as the first degree streams. When two first degree streams join, they make up a second degree stream and when two second degree streams join, they make up a third degree stream. This ordering continues to the outlet of the basin.

In the method given by Strahler [5]-[7] a stream, which takes no other branch but overland flow as shown by number 1 in Figure 1, is called a first order stream. When two first order streams join, they make up a second order stream as shown by number 2 in Figure 1, a third order stream is produced when two second order streams are joined and can also take in other first and second order streams as shown by number 3 in Figure 1. This procedure is continued until the outlet of the basin and the order of the basin is equal to the order of the main stream (defined by number 4 in Figure 1) which is the longest branch in the basin. Shreve also defined a method for stream and basin ordering. Shreve's definition of the first order branches is the same as Strahler's method, but from then on branches take an order value, which is the summation of the orders of joining branches [1]. Strahler-Horton system is widely used among the methods

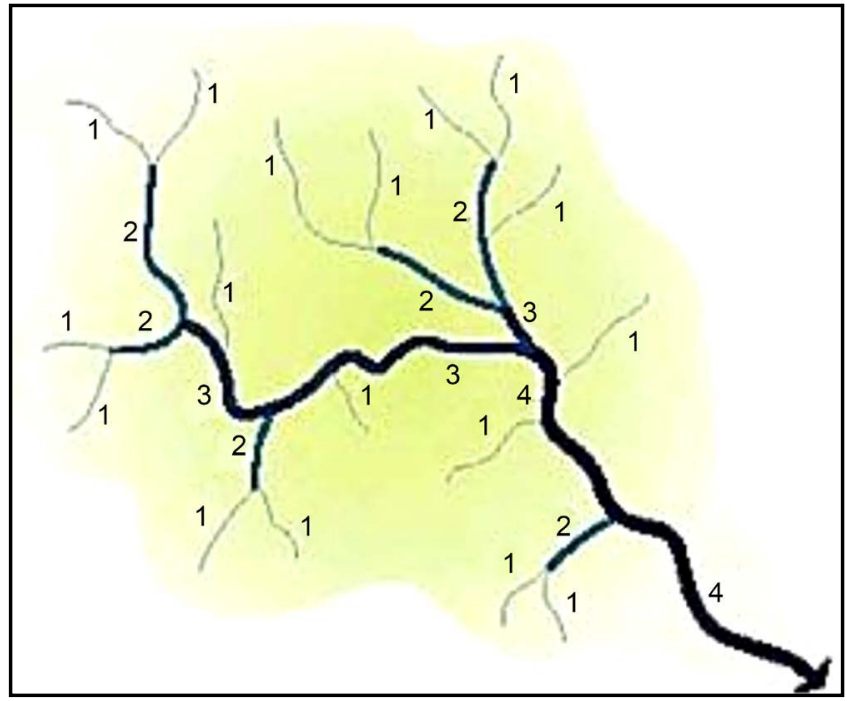

Figure 1. Strahler-horton stream ordering system. 
described above for ordering the streams and basins (Figure 1).

In order to design the structure of a river network topologically, the river network and its drainage area must be coupled so that the interaction between them can be established for coding. In general, Pfafstetter Coding System is used to achieve this work. This coding system gives information on natural channels, manmade irrigation and drainage canals, natural lakes, and reservoirs, shorelines, islands, and boundaries of the basin. In this system, branches of a river draining at most four major subareas are numbered evenly with single digit numbers, starting from downstream toward upstream. Inter-basins drained by the main branch are also numbered oddly with a single digit number starting from downstream toward upstream. The drainage area of the upstream branch numbered with 9 is always greater than the drainage area of the side branch numbered with 8 as seen in Figure 2 below. If there is a closed basin and/or a sub-basin, it is numbered with " 0 ". If the main river channel discharges to the sea, it is numbered with "1" [8] [9].

Several countries derived their own river coding by using the Strahler-Horton system. United States Geological Survey developed "Hydrological Unit Code-HUC" for river basin coding. 1/250,000 scaled topographic maps were used during the first application of this coding. In this first application study, basins were categorized as Region, Sub-region, Accounting, and Catalog Units and each of these hydraulic units received HUC code consisting of 8 characters as "rr ss aa cc". In this coding system "Region" is the first level hydraulic unit that includes main rivers or river systems discharging to a bay. "Sub-Region" is the second level hydraulic unit that includes main rivers, closed basins, and rivers discharging to the coastal zones. "Subregions" in the third level are divided into "accounting-units". "Catalog Units" are the fourth level hydraulic units that include water collecting areas known as watersheds. This coding system was revised in 2010, and the new revised code consists of 12 characters that include six levels. In Germany, basin coding studies started in 1993 by a group named "Landerarbeitsgemeinschaft Wasser-LAWA" [10]. In this study, water contribution zones, consistent with hierarchical numerical numbers in the basin, were taken into consideration. As

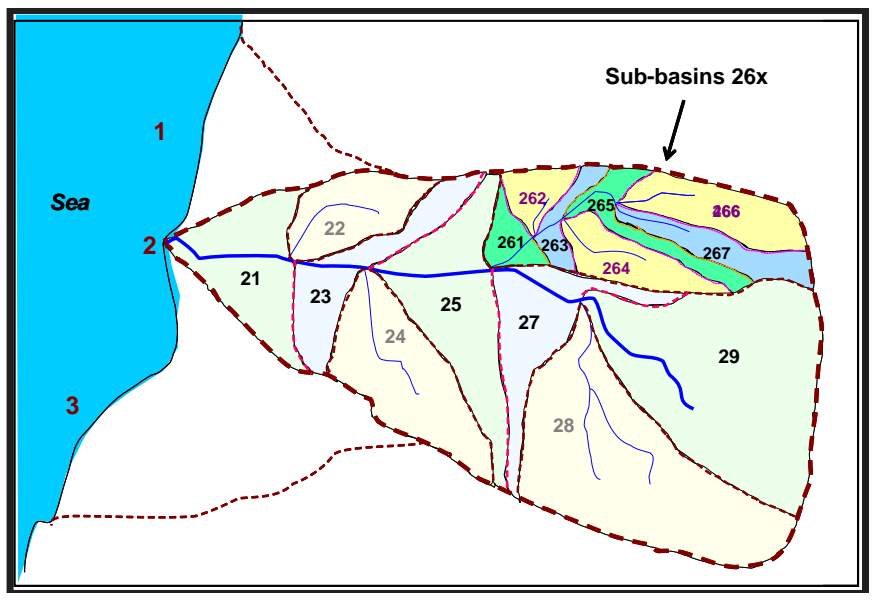

Figure 2. Pfafstetter basin coding. 
a result of this study Germany was divided into six basins, namely the Donau with coding number 1, the Rheine with coding number 2, the Ems with coding number 3, the Wesser with coding number 4 , the Elbe with coding number 5, and the Oder with coding number 6 . As in the Pfafstetter coding system, 4 main river branches in each basin were considered in the coding studies. However, the direction of the coding study in LAWA system started from upstream toward downstream in contrast to pfafstetter coding system [10]. REGINE coding system is used in Norway. This system was developed by Norwegian Water Resources and Energy Administration in the context of Norwegian Water Information System. Rivers longer than $10 \mathrm{~km}$, lakes greater than 1 $\mathrm{km}^{2}$ surface area, reservoir areas and tunnel entrance locations were all considered in the REGINE system. In this system alphanumeric combination of coding was used for the determination of regions of the hydrologic drainage areas. Those regions were converted to main basins with single outlets [10]. Portuguese Institute for Water Resources also performed a study for river basin coding for those watersheds larger than $1 \mathrm{~km}^{2}$. Portuguese hydrologists studied basin coding of various European basins and decided to use pfafstetter coding system for their river basins. This coding system may also provide a basis data for the European Water Framework Directive studies [11] [12]. Romania used Gravelius method for coding the Danube River which is the main river of Romania [13]. European Environmental Agency (EEA) conducted a feasibility study to develop a database of the boundaries of the transboundary rivers that are of common interest to various nations of Europe. Based on this feasibility study of EEA, low resolution maps with $1 / 100,000$ scale and medium resolution maps with 1/25,000 scale were used in a pilot study to form a basin database to provide for the urgent data needs of the European nations. A river basin coding system known as ERICA-CS was developed within the framework of this project. This coding system was developed by using $1 / 25,000$ scale river network that is based on pfafstetter coding system. This coding system is named as modified pfafstetter coding system and it is defined as "MM BBB N1 $\mathrm{N} 2 \mathrm{~N} 3 \mathrm{~N} 4 \mathrm{~A}$ ", where MM is the marine code, $\mathrm{BBB}$ is the marine border code, N1 N2 N3 N4 is the nested catchment code, and A is the area band [14]. The modified pfafstetter coding system was modified in 2012 by including a country code at the beginning of the coding and also by increasing the nested catchment code from 6 digits to 22 digits so that each of the stream levels are incorporated into the coding [15].

In 1999, Joint Research Center of the European Commission launched a study on a database for basin boundaries and river networks of Europe within the context of "Euro Landscape" Project, and by using 1/250,000 - 1/500,000 scaled maps. Findings of this study were published under the title "Catchment Characterization and Modelling" (CCM). Later on, Space Shuttle Topography Mission-SRTM data were combined with the Catchment Characterization and Modelling database to obtain the Digital Elevation Maps of Europe, and CCM study was revised as CCM2 [16]. "European Catchments and Rivers (ECRINS)" was developed by incorporating Corrine Land Cover and Water Framework Directive reports into CCM2 in 2012 [16]-[18].

A study was also performed to develop hydrological river basin coding for Turkish 
river catchments based on the evaluation of the ECRINS coding system, briefly discussed above. The developed hydrological river coding is flexible and versatile for all types of basins in Turkey. Using this hydrological river basin coding will define river basin boundaries accurately, prevent conflicts in sectorial water allocation caused by uncertainty in locations of water source, produce a base for determining water potential and estimating extreme hydrological events of the basin, produce a basis for the prevention of water disputes among stakeholders within the basin, and help implementation of IWRM at basin level.

\section{Methodology for the Derivation of the River Basin Coding in Turkey}

Hydrological river basin coding developed in this study is based on the European Catchments and River Network System-ECRINS, and is defined in the Table 1 given below.

The priority matters for the development of basin and sub basin studies for rivers and basins in Turkey are as follows: Hydrological River Basin coding developed for Turkish river basins should meet the needs of the reports requested by the European Union, should easily be adoptable to other coding studies, and should protect areas and hydrological structures of the existing 25 river basins and sub basins of Turkey. The general form of the code that covers all these points is given in Table 1. In this table the country code MS is defined and published by "ISO 3166-1-ALPHA-2". For example TR is used for Turkey. In Table 1 code BD defines the river basin district code shown in Figure 3, which is a special code for Turkey especially from the management point.

Even though Turkey is divided into 25 river basins, this division does not show the features of actual hydrological river basins as defined under the Strahler-Horton system. Those 25 basins may not only cover the major rivers but may also cover small basins in the coastal zones whose creeks discharge directly to the seas. Gediz, Buyuk Menderes, Kizılırmak, Yesilırmak, Sakarya, and Ceyhan river basins are this type of basins. In order to include the small basins which is actually do not contribute their discharge to the major river of the basin, River Basin District (RBD) definition is adopted (Figure 3) and included in the coding. Thus, small creeks that discharge directly to the Marmara Sea, the Eastern and Western Black Sea, and the Mediterranean sea regions are grouped to form one basin in the respective regions. This approach is also adopted in closed basins such as the Konya, the Lake Van, the Akarcay, and the Burdur-Beysehir Lakes closed basins. This definition is also consistent with the European Water Framework Directive.

Table 1. Hydrological river basin coding in Turkey.

\begin{tabular}{ccccc}
\hline $\begin{array}{c}\text { Country } \\
\text { Code }\end{array}$ & $\begin{array}{c}\text { River Basin } \\
\text { District Codes }\end{array}$ & $\begin{array}{c}\text { Sea/lake } \\
\text { Code }\end{array}$ & $\begin{array}{c}\text { Coastline } \\
\text { Code }\end{array}$ & $\begin{array}{c}\text { Nested Catchment } \\
\text { Code }\end{array}$ \\
\hline MS & BD & HS & C & P \\
2 digits & 2 digits & 2 digits & Maximum 5 digits & Maximum 12 digits \\
& & MSBD.HS.CCCCC.PPPPPPPPPPP & \\
\hline
\end{tabular}




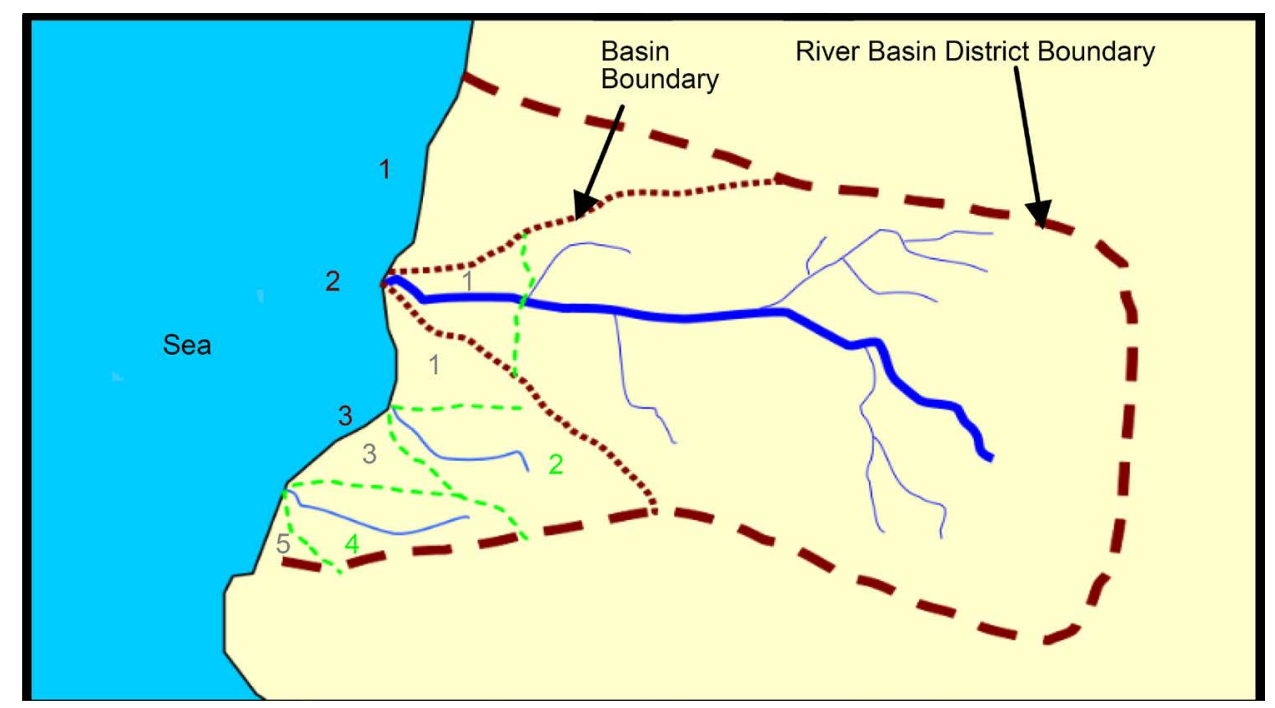

Figure 3. River basin district definition (RBD).

On the other hand, Turkey has transboundary basins where the river originates in the Turkish territory and discharges to the seas in the neighboring countries. The Euphrates, the Tigris, the Aras, and the Çoruh rivers originate from Turkey, and then cross from the boundary of Turkey and discharge to the sea within the neighbor country. The Maritza river (Meriç) and the Orontes river (Asi) originate from the neighbor country and discharge to the sea in Turkey. Portions of these transboundary river basins that are located within the Turkish territory are considered and adopted to the River Basin District (RBD) definition (Figure 4).

In Table 1, the code $\mathrm{H}$ defines Hydrological System Number. This number defines whether the major river of the basin is discharging to the Mediterranean Sea, Black Sea, Persian Gulf, Caspian Sea or inland lakes within Turkey. Alphabetic capital characters are used for defining hydrological system code. For example, code " $\mathrm{M}$ " is used for basins that contribute their discharge to the Mediterranean Region. Studies done for the development of water resources projects for the 25 Basins in Turkey are all evaluated, and those 25 basins are named as River Basin Districts in Turkey is shown in Figure 4 and Table 2.

Results of hydrological studies done in these basins showed that some of the streams and creeks considered within the Euphrates-Tigris River Basin are actually located in the Lake Orumiyeh Closed Basin and in the Orontes River Basin. Moreover, some of the creeks considered in the Lake Van Closed Basin are actually within the Aras River Basin. In order to be consistent with the previous studies done for those 25 basins, same names were used in the River Basin District definition developed in this study. However, hydrologists must be aware that these basins are not defined by Strahler-Horton systems, but are defined as River Basin Districts (RBD).

It is important to define whether a river is discharging to a sea or an inland water body (lake) for the coding system developed for Turkish river basins in this study. A two-digit code is used to be consistent with "ECRINS" coding system. According to the 
"ECRINS" coding system, rivers and streams do not necessarily discharge to the same sea or lake, as in the case of The Marmara Basin and The Konya Closed Basin. Thus rivers discharging to different water bodies are coded with the codes defined for those water bodies. Table 3 defines the codes of those water bodies used in this study.

Even though their codes are taken from "ECRINS" coding system, the codes of the Marmara Sea, the Akşehir Lake, the Burdur Lake, the Acıgöl, the Hotamış Lake, and the Akgöl which are not defined in the "ECRINS" Coding system, are integrated into the "ACRINS" Coding system in this study as shown in Figure 5 and Table 4. As shown in Table 4 rivers in the Marmara River Basin District are discharging to three different seas with different codes.

After the determination of Country Code, Basin District Code and Hydrological System Code, the remaining part of the coding consists of the coastal and sub basin codes. Coastal code is an important variable used in this study and the Pfafstetter Coding System was used to define this variable in the coding system. This coding for the coastal areas follows the procedure where four largest river basins on the Black Sea coast of Turkey, discharging to a sea, are taken and coded with even numbers as 2, 4, 6 and 8. Areas situated in-between those four large basins, known as inter basins, are coded with

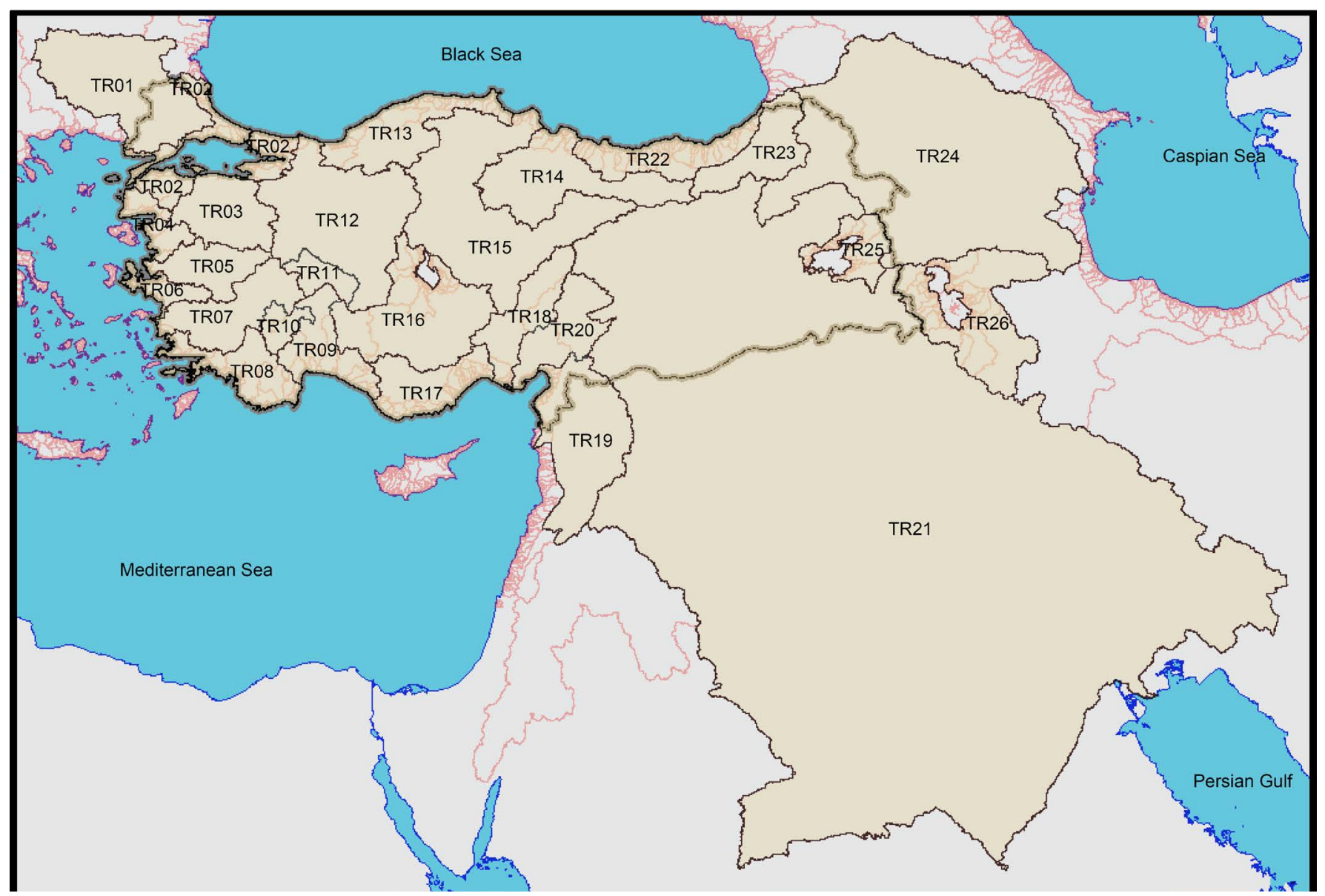

Figure 4. River basin districts in Turkey. 
Table 2. River basin districts (RBD) in Turkey.

\begin{tabular}{|c|c|c|}
\hline Number of Basins & River Basin District Number & River basin district Name \\
\hline 1 & TR01 & Maritza River Basin \\
\hline 2 & TR02 & Marmara River Basin \\
\hline 3 & TR03 & Susurluk River Basin \\
\hline 4 & TR04 & North East Mediterranean River Basin \\
\hline 5 & TR05 & Gediz River Basin \\
\hline 6 & TR06 & Küçük Menderes River Basin \\
\hline 7 & TR07 & Büyük Menderes River Basin \\
\hline 8 & TR08 & West Mediterranean River Basin \\
\hline 9 & TR09 & Antalya River Basin \\
\hline 10 & TR10 & Burdur River Basin \\
\hline 11 & TR11 & Akarçay River Basin \\
\hline 12 & TR12 & Sakarya River Basin \\
\hline 13 & TR13 & West Black Sea River Basin \\
\hline 14 & TR14 & Yeşilırmak River Basin \\
\hline 15 & TR15 & Kizılırmak River Basin \\
\hline 16 & TR16 & Konya Basin \\
\hline 17 & TR17 & East Mediterranean River Basin \\
\hline 18 & TR18 & Seyhan River Basin \\
\hline 19 & TR19 & Orontes River Basin \\
\hline 20 & TR20 & Ceyhan River Basin \\
\hline 21 & TR21 & Euphrates-Tigris River Basin \\
\hline 22 & TR22 & East Black Sea River Basin \\
\hline 23 & TR23 & Chorkhi River Basin \\
\hline 24 & TR24 & Aras River Basin \\
\hline 25 & TR25 & Lake Van Basin \\
\hline 26 & TR26 & Lake Orumiyeh Basin \\
\hline
\end{tabular}

Table 3. Codes used for defining the hydrological systems of the particular basins.

\begin{tabular}{cccc}
\hline Hydrological System & Sea/Lake & Code & Endorheic System \\
\hline \multirow{2}{*}{ Mediterranean Sea } & M & 4 & North East Mediterranean \\
& M & 5 & Egean) \\
Caspian Lake & M & 6 & Marmara Sea \\
Lake Van & C & 1 & Caspian Lake \\
Indian Ocean & V & 9 & Lake Van \\
& I & 1 & Lake Burdur \\
Salt Lake & Z & 9 & Salt Lake \\
& Z & 7 & Beysehir Lake \\
Akarçay Lake & Z & 6 & Hotamiş Lake \\
Burdur Lake & $\mathrm{Z}$ & 5 & Ak Lake \\
& $\mathrm{K}$ & 9 & Akşehir Lake \\
& $\mathrm{U}$ & 9 & Burdur Lake \\
& $\mathrm{U}$ & 7 & Acı Lake \\
\hline
\end{tabular}




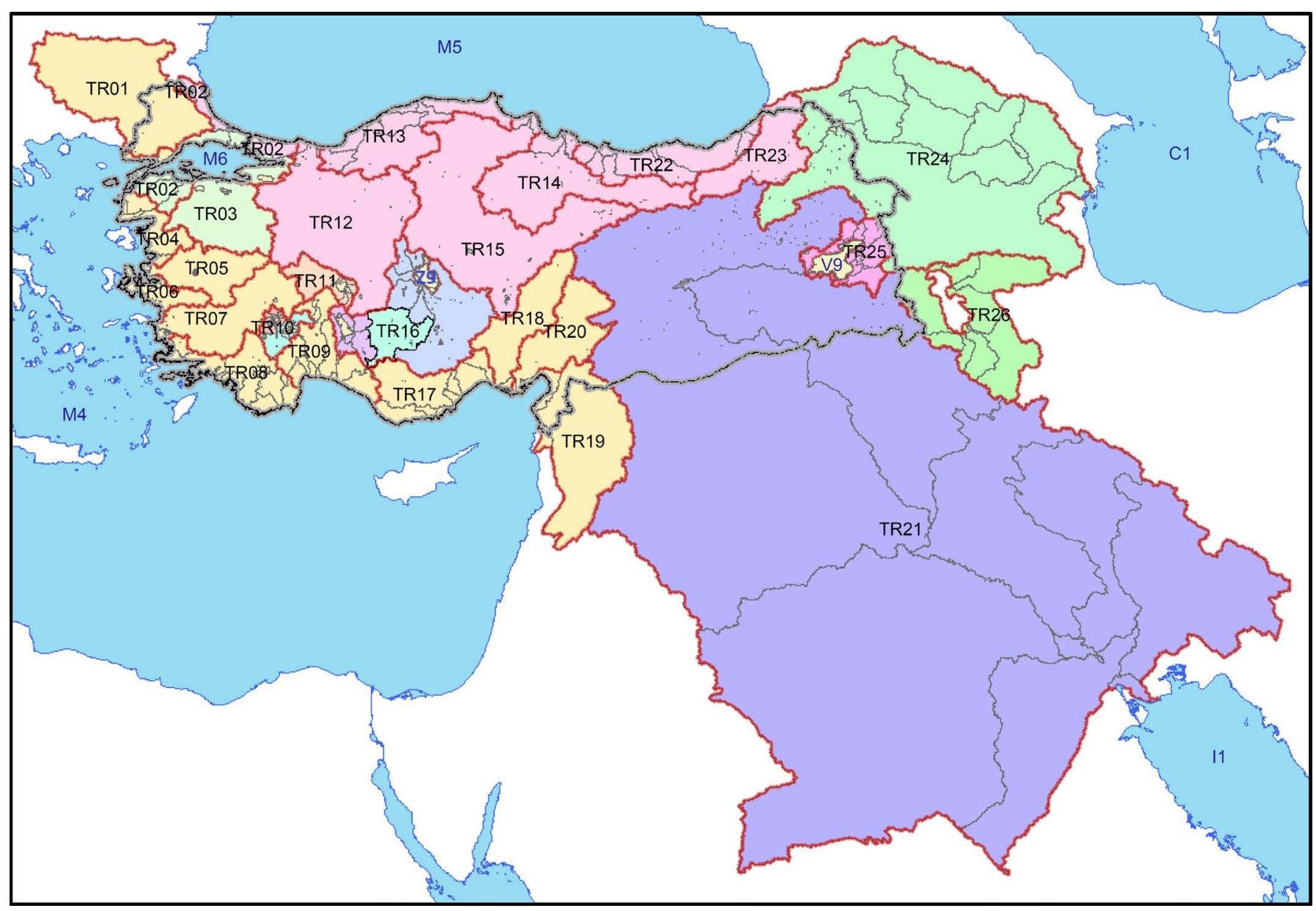

Figure 5. River basin district codes in Turkish basins.

Table 4. Basin district codes of Turkish basins.

\begin{tabular}{ccc}
\hline Sea Code & Sea/Lake Name & Basin Codes \\
\hline M4 & North East Mediterranean & TR01.M4; TR02.M4; TR04.M4;TR05.M4; TR06.M4; TR07.M4; TR08.M4; TR09.M4; \\
M5 & Black Sea & TR17.M4; TR18.M4; TR19.M4; TR20.M4 \\
M6 & Marmara Sea & TR02.M5; TR13.M5; TR14.M5; TR15.M4; TR22.M5; TR23.M5 \\
C1 & Caspian Lake & TR02.M6; TR03.M6 \\
V9 & Lake Van & TR24.C1 \\
I1 & Persian Gulf & TR25.V9 \\
Z9 & Salt Lake & TR21.I1 \\
Z7 & Beysehir Lake & TR16.Z9 \\
Z6 & Hotamış Lake & TR16.Z7 \\
Z5 & Ak Lake & TR16.Z6 \\
K9 & Akşehir Lake & TR16.Z5 \\
U9 & Burdur Lake & TR11.K9 \\
U7 & Acı Lake & TR10.U9 \\
& & TR10.U7
\end{tabular}


odd numbers as $1,3,5,7$, and 9. Basins coded with even numbers are the main river catchments which can also be divided into smaller sub basins and coded by using Pfafstetter Coding System (Figure 6).

As can be seen from Figure 6, large river basin areas in the eastern Black Sea zone are coded as TR22.M5.2 and the inter basins are coded with TR22.M5.3. These areas can also be divided into subareas and coded by using Pfafstetter coding system. For example, in closed basins if the streams are discharging to a natural lake, the coding of the drainage areas is done in the clockwise direction according to Pfafstetter system (See Figure 7).

\section{Application of the Method to Turkish River Basins}

In order to show the flexibility and versatility of the coding system, as defined in Tables 1-4, it was applied to one of the major river basins in Turkey, the Yesilirmak River Basin, which has all the complexities in terms of small sub-basins that do not contribute their flows to the main river branch in the basin. This basin is located in the coastal region of the Black Sea in the Northern sector of Turkey (Figure 8). This basin takes its name from the main river which is called the Yeşilirmak River (Figure 9).

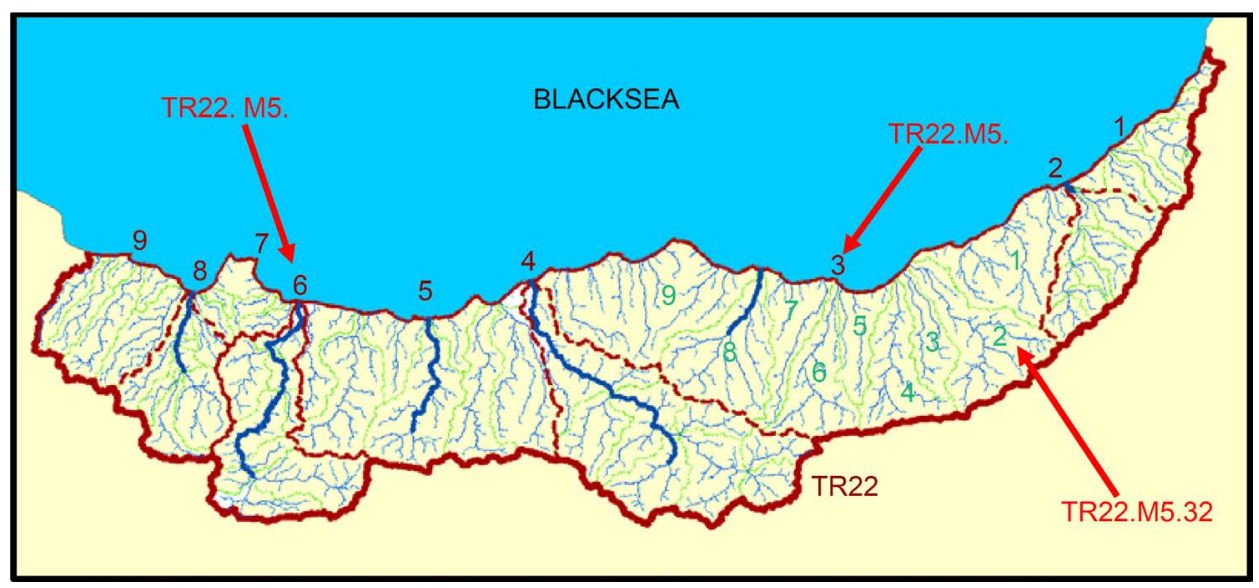

Figure 6. Coding of basins located in the eastern Black Sea coastal zones.

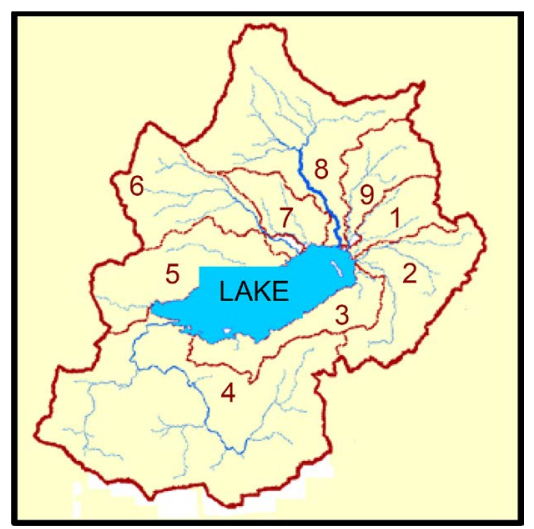

Figure 7. Coding procedure of the closed basins. 


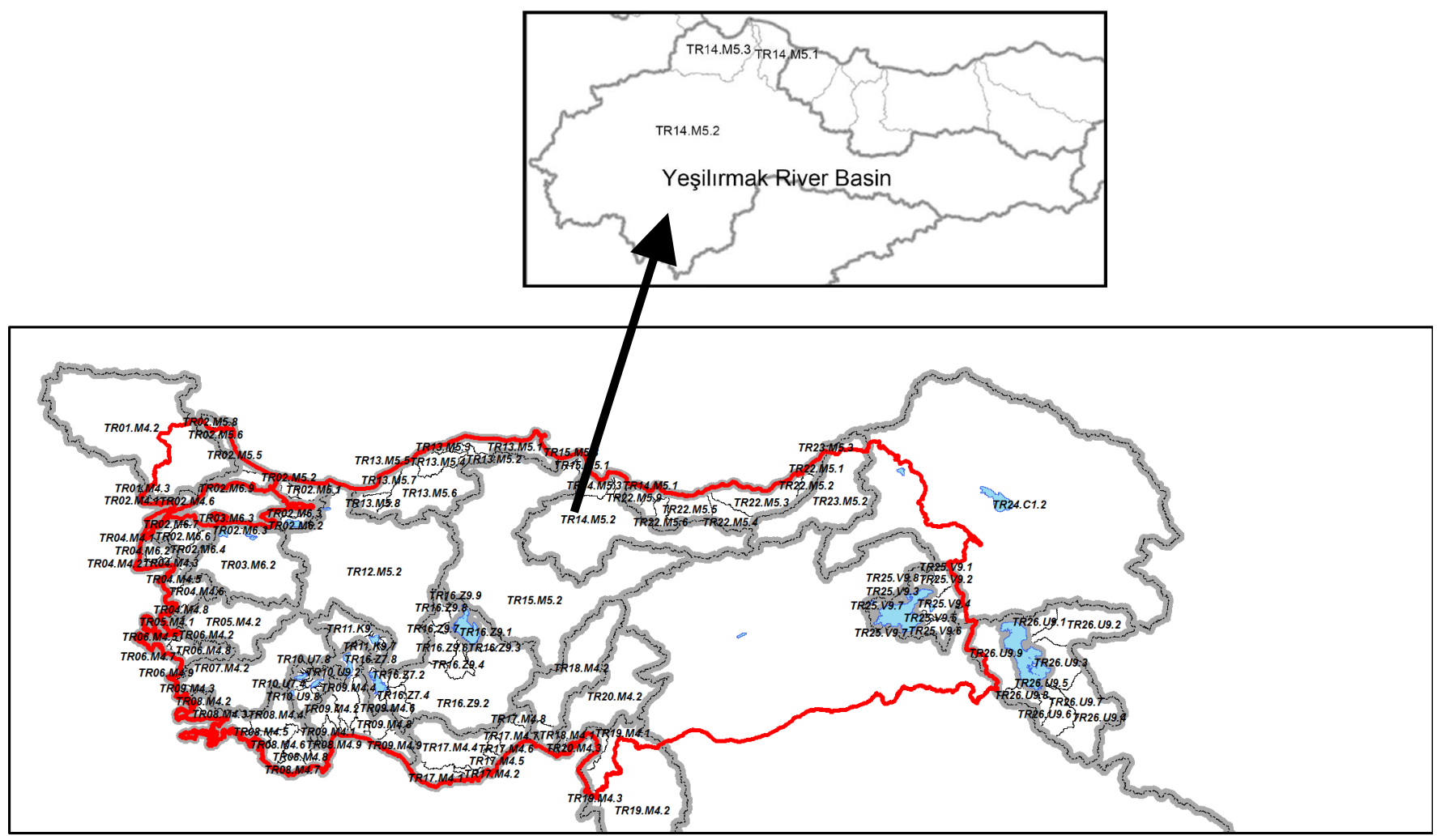

Figure 8. Location of the Yeşilirmak River Basin.

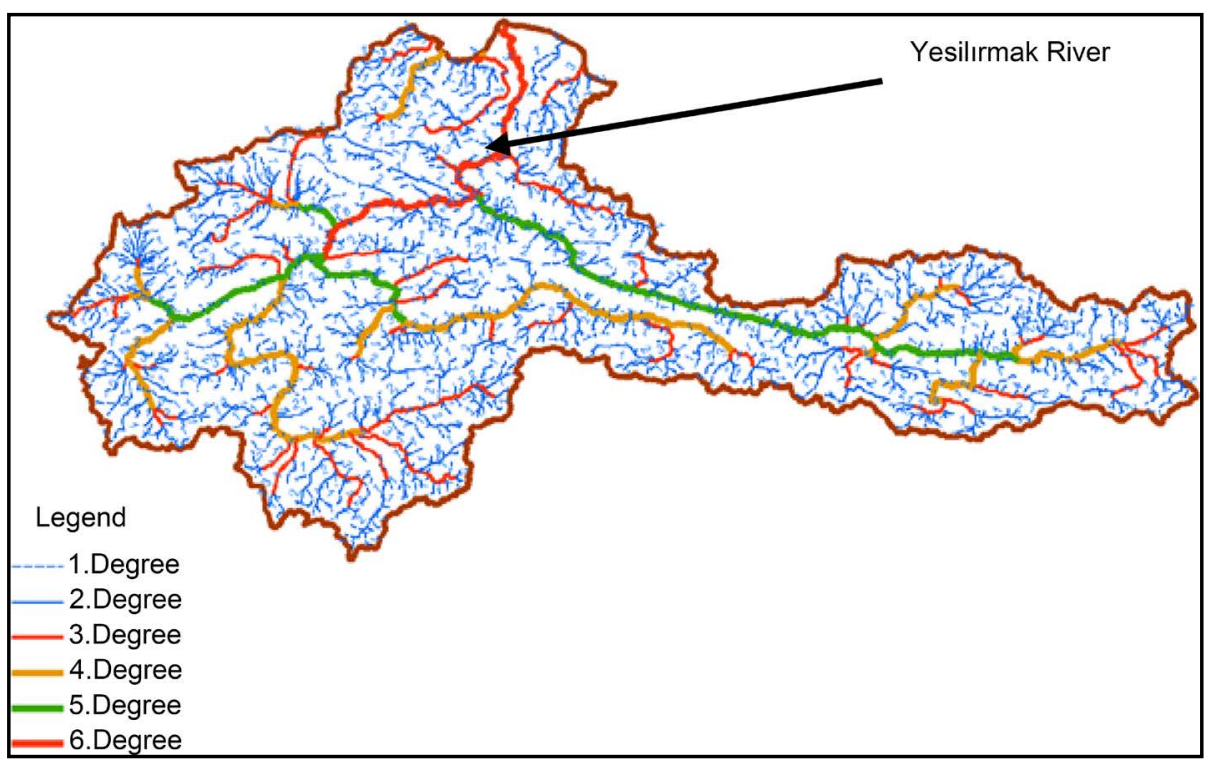

Figure 9. Yeşilırmak River Basin and drainage network.

Figure 9 depicts the drainage network of the Yeşilırmak River basin at six different degrees. The degrees of the drainage system are shown by different colors that are determined by the Pfafstetter coding system. According to the Pfafstetter coding system, sub basins of this basin were determined as follows (please see Figure 10). The main 
drainage area of the Yeşilirmak River is defined by TR14.M5.2. The main subareas located at the outlet of the Yeşilirmak River Basin and discharging directly to the Black Sea, are coded by TR14.M5.1 at the right side of the Yeşilırmak River outlet and TR14.M5.3 at the left side of the Yeşilırmak River outlet. The main drainage area, coded by TR14.M5.2, is further divided into subareas starting from the downstream to the upstream of the Yeşilırmak River. Sub-basins that have the largest areas are determined as the main sub-basins and are coded by even numbers 2, 4, 6 and 8 . The remaining sub areas depicting inter-basin characteristics are coded by odd numbers 1, 3, 5, 7 and 9 as shown in Figure 10. Based on the Pfafstetter coding system, the whole Yeşilırmak river basin is divided into 9 sub-basins.

Even though the dashed circle area, shown in Figure 10, is located at the left side of the Yeşilirmak River Outlet, and is part of the Yeşilırmak River Basin, it does not contribute its discharge to the Yeşilırmak River. This area discharges directly to the Black Sea as shown in Figure 11. The same approach, defined above for coding of the sub-basins, is adopted for determining the codes of the sub-basins and inter-basins of this area. Figure 11 also shows how this section of the Yeşilırmak River basin is coded so that even though it is considered as part of the Yeşilırmak River basin by the district code 14M5, the discharge of the Yeşilırmak River will not be influenced at all when a water resources development project is planned for this section of the basin. The remaining part of the Yeşilırmak River basin contributes all its discharge to the Yeşilirmak River flow.

The second example application of the developed coding system is adopted to the Akarcay closed basin shown in Figure 12. The Akarcay river is one of the important inland water resources of the Afyonkarahisar province. This river originates from the north of the city of Afyonkarahisar, then drains all the areas Afyonkarahisar province and discharges to the inland Eber Lake first. It then hydraulically connects the Eber

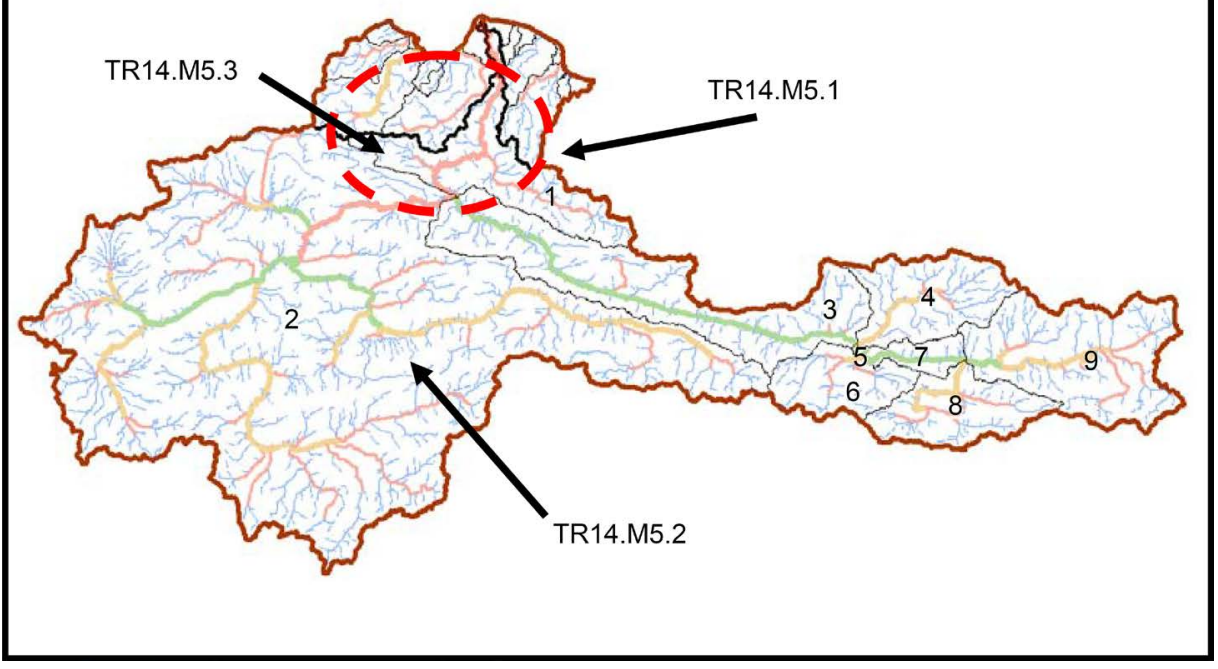

Figure 10. Main sub areas of the Yesilirmak River Basin. 


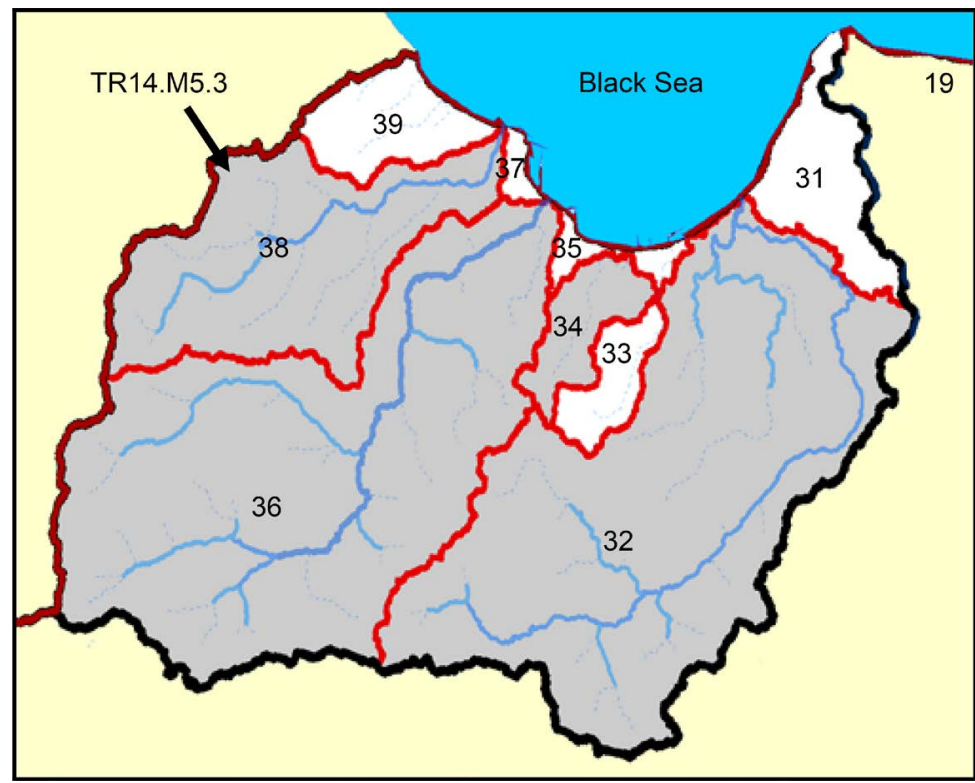

Figure 11. Coding of the northern section of the Yeşilırmak River Basin.

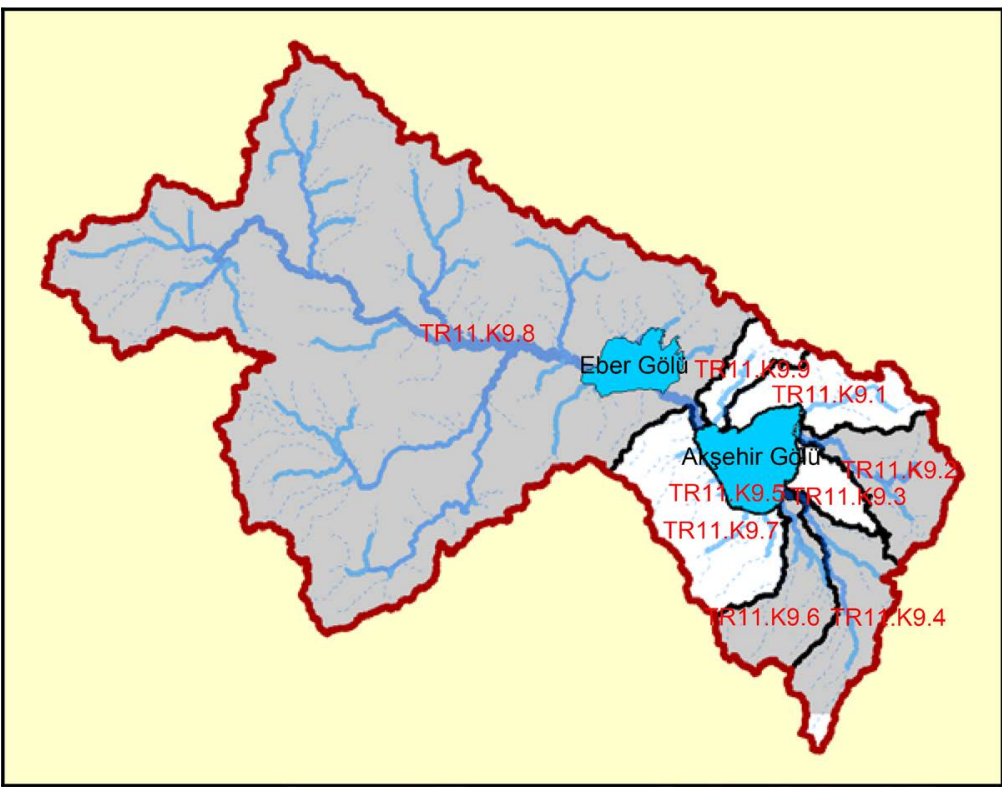

Figure 12. The Akarçay Closed Basin.

and the Akşehir inland Lakes as shown in Figure 12.

With the above-given definitions, the coding system developed for Turkish river basins works accurately and is applicable to all kinds of basins, such as the closed basins (Lake Van, and Konya), and Transboundary basins (Meriç (Maritza), Çoruh (Chorokhi) and Tigris-Euphrates).

\section{Discussion}

The developed coding system was applied to all 25 river basins in Turkey to determine 
whether it is applicable to the delineation of the watershed boundaries accurately provided that digital elevation map (DEM) information with high resolution is available. This coding, developed for Turkish river basins, is also appropriate for the management of Turkish water resources by State Hydraulic Works (DSI) which is the main water authority in Turkey. Turkey is divided into 25 hydrological river basins where at each basin Regional Water Authorities (DSI Regional Directorates) are established in order to prepare and implement basin-wide water resources development projects. To prevent conflict in sectorial water allocation and water disputes among the stakeholders in the basin, it is important to determine the watershed boundary along with its surficial drainage system. The coding system developed in this study provides a base for the solution of such problems. For example, if a project is developed for the Yeşilırmak River basin to supply water for agriculture, environment, industry, hydropower, and domestic use, after allocating all the water needs of the different sectors, baseflow of the river should always drain into the river channel. The stakeholders living at the very upstream of the Yeşilırmak River basin which is not contributing its flow to the Yeşilırmak River, may not be influenced by the impacts of the project on the Yeşilırmak River, because this part of the basin has its own water supply and drainage system even though it is considered to be within the Yeşilirmak River basin. The appropriate sub-basin delineation analysis can be done precisely by the help of the coding system described above. The coding described above not only prevents conflicts in sectorial water allocation caused by uncertainty in the locations of the water sources, but also provides a base for determining the water potential and estimating the extreme hydrological events of the basin. Similar analysis can also be done for closed basins and for transboundary basins easily.

\section{Conclusions}

GIS technologies have been extensively used in hydrological studies during the last two decades. Using GIS in the determination of watershed boundaries enables the water resources planners, hydrologists, engineers and academicians to determine water potentials, to estimate extreme hydrological events, to allocate water for agriculture, hydropower, industry and domestic uses, for water transmission between watersheds and for management of transboundary basins during floods and draughts.

A study was performed to develop hydrological river basin coding for Turkish river basins. In this development, firstly ECRINS and pfafstetter methods were combined and secondly River Basin District concept was incorporated into the coding so that the sub areas which are parts of the basin but do not contribute their discharges to the major river of the basin, are accounted within the system. The developed hydrological river coding system is flexible and versatile for all types of basins in Turkey. In order to demonstrate the flexibility and accuracy of the coding system, it was applied to three river basins in Turkey each of which have complex hydological and topographical features that are different from each other. These basins are the Yeşilirmak River basin which is one of the major river basins discharging to the Black Sea, the Maritza (Meriç) 
River basin which is a transboundary river basin, and the Akarçay Closed Basin that is drained by the Akarçay River that discharges to the inland Eber and Akşehir lakes. These applications showed that using the developed hydrological river basin coding defines river basin boundaries accurately. The accurate delineation of basin boundaries is helpful in the planning of a water resources development project, eliminates or minimizes uncertainty in sectorial water allocation caused by locations of water sources, produces a base for determining the water potential and estimating extreme hydrological events of the basin, produces a basis for the prevention of water disputes among stakeholders within the basin, and helps the implementation of IWRM at basin level.

\section{References}

[1] Dooley Jr., J.F. (2003) A Report in Three Sections Including Topical Annexes. Spatial Standards \& Norm Task Force (SSN-NF), Annex 1: Ranking and Topological Encoding Schemes, Food and Agriculture Organization of the United Nations.

[2] Zăvoianu, I., Herişanu, G. and Cruceru, N. (2009) Classification Systems for Hydrographical Network. Forum Geographic, 58-63.

[3] Horton, R.E. (1932) Drainage Basin Characteristics. Transaction of the American Geophysical Union, 13, 350-361. http://dx.doi.org/10.1029/TR013i001p00350

[4] Horton, R.E. (1945) Erosional Development of Streams and Their Drainage Basins: HydroPhysical Approach to Quantitative Morphology. Geological Society of American Bulletin, 56, 275-370. http://dx.doi.org/10.1130/0016-7606(1945)56[275:EDOSAT]2.0.CO;2

[5] Strahler, A.N. (1957) Quantitative Analysis of Watershed Geomorphology. American Geophysical Union Transactions, 38, 913-920. http://dx.doi.org/10.1029/TR038i006p00913

[6] Suzanne, M.P., Rosenbaum, B.J., McKay, L.D. and Dewald, T.G. (2008) Strahler Stream Order and Strahler Calculator Values in NHDPlus. SOSC Technical Paper. http://www.epa.gov/waters

[7] Usul, N. (2013) Engineering Hydrology, 3rd Edition, METU Press, Ankara.

[8] Globevnik, L., Vrenko, D.Z., Jensen, H.M. and Kovačič, M. (2010) Proposed Coding of European Rivers for Water Framework Directive. Ohrid.

[9] Verdin, K.L. and Verdin, J.P. (1999) A Topological System for Delineation and Codification of the Earth's River Basins. Journal of Hydrology, 218, 1-12. http://dx.doi.org/10.1016/S0022-1694(99)00011-6

[10] Britton, P. (2002) Review of Existing River Coding Systems for River Basin Management and Reporting. Prepared as a Contribution to the WFD GIS Working Group. http://193.178.1.168/River_Coding_Review.htm

[11] Nery, F., Sousa, R. and Matos, J. (2001) Development of an Indirect Spatial Reference System for the Portuguese River Basins. https://www.researchgate.net/publication/228950275_Development_of_an_Indirect_Spatial Reference_System_of_the_Portuguese_River_Basins

[12] Middle East Strategic Research Center (ORSAM) Report No. 154 (2013) ORSAM Water Research Program Report No. 19-“European Water Framework Directive - Transboundary Waters. Ankara, May 2013. (In Turkish)

[13] Brilly, M. (2010) Danube River Basin Coding. Hydrological Process of the Danube River Basin: Perspective from the Danubian Countries, Springer, Slovenia, 125-142.

http://dx.doi.org/10.1007/978-90-481-3423-6_4 
[14] Flawin, R.W., Andrews, A.J., Kronvang, B., Müller-Wohlfeil, D., Demuth, S. and Birkenmayer, A. (1998) ERICA; Europen Rivers and Catchments. European Environmental Agency, Copenhagen, 69-88.

[15] EC (2010) Proposal for a European Coding System for Hydrological Features. Guidanced Document No.9-Implementing the Geographical Information System Element (GIS) Elements of the EU Water policy, WFD. Draft Revision of Appendix 7, 40-43.

[16] Voght, J. and Foisneau, S. (2007) CCM River and Cathchment Database. Version 2.0, Analysis Tools.

http://agrienv.jrc.ec.europa.eu/publications/pdfs/CCM2-Tools-EUR22649EN-2007.pdf

[17] EC (2010) European Coding System for Hydrological Features. Guidanced Document No.22-Updated Guidance on Implementing the Geographical Information System (GIS) Elements of the EU Water Policy, WFD, 101-106.

[18] Vogt, J.V. (Ed.) (2002) Guidance Document on Implementing the GIS Elements of the Water Framework Directive. European Commission-JRC (Report No. EUR 20544 EN), Ispra, $172 \mathrm{p}$.

Submit or recommend next manuscript to SCIRP and we will provide best service for you:

Accepting pre-submission inquiries through Email, Facebook, LinkedIn, Twitter, etc.

A wide selection of journals (inclusive of 9 subjects, more than 200 journals)

Providing 24-hour high-quality service

User-friendly online submission system

Fair and swift peer-review system

Efficient typesetting and proofreading procedure

Display of the result of downloads and visits, as well as the number of cited articles

Maximum dissemination of your research work

Submit your manuscript at: http://papersubmission.scirp.org/

Or contact jwarp@scirp.org 